\title{
THE CONTENT OF SELENIUM IN SOME SPECIES OF MEADOW PLANTS*
}

\author{
Barbara Patorczyk-Pytlik \\ Chair of Plant Nutrition \\ Wroclaw University of Environmental and Life Sciences
}

\begin{abstract}
The aim of the investigation carried out in 2006-2007 was to assess differences between 5 grass species and 5 species of plants belonging to meadow herbs in their ability to accumulate selenium. According to the results, among the grass species, the samples of Arrhenatherum elatuis L. had the highest average Se content (46 $\mu \mathrm{g} \mathrm{Se} \cdot \mathrm{kg}^{-1} \mathrm{~d} . \mathrm{m}$.), and the lowest average Se amount was found in Holcus lanatus L. $\left(24 \mu \mathrm{g} \mathrm{Se} \cdot \mathrm{kg}^{-1} \mathrm{~d}\right.$.m.). The content of Se in meadow weeds $\left(70 \mu \mathrm{g} \mathrm{Se} \cdot \mathrm{kg}^{-1} \mathrm{~d} . \mathrm{m}\right.$.) was approximately twice as high as in grasses (32 $\mu \mathrm{g} \mathrm{Se} \cdot \mathrm{kg}^{-1} \mathrm{dm}$.). Among this group of plants, the highest Se accumulation occurred in Equisetum arvense L. (103 $\mu \mathrm{g} \mathrm{Se} \cdot \mathrm{kg}^{-1} \mathrm{dm}$.) and the lowest - in Taraxacum officinale (59 $\mathrm{\mu g} \mathrm{Se} \cdot \mathrm{kg}^{-1} \mathrm{dm}$.). Both in grasses and in meadow weeds, the Se content significantly depended on the amount of this element in soils. In the following species: Dactylis glomerata L., Arrhenatherum elatius L., Poa pratensis L. and Taraxacum officinale, the amount of accumulated Se was also conditioned by the soil's abundance in organic and total $\mathrm{C}$.
\end{abstract}

Key words: Se, soils, grasses, herbs.

\section{ZAWARTOŚĆ SELENU W NIEKTÓRYCH GATUNKACH ROŚLIN LĄKOWYCH}

Abstrakt

Celem badań prowadzonych w latach 2006-2007 było określenie zróżnicowania w zdolności nagromadzania selenu przez 5 gatunków traw oraz 5 gatunków roślin zaliczanych do ziół łąkowych. Wykazano, że wśród analizowanych gatunków traw najwięcej selenu zawierały próby Arrhenatherum elatuis L. (46 $\mu \mathrm{g} \mathrm{Se} \cdot \mathrm{kg}^{-1} \mathrm{sm}$.), a najmniej Holcus lanatus L. (24 $\mu \mathrm{g} \mathrm{Se} \cdot \mathrm{kg}^{-1} \mathrm{sm}$. ), średnio dla badanych gatunków roślin.

dr hab. Barbara Patorczyk-Pytlik, associate prof. UP, Chair of Plant Nutrition, Wroclaw University of Environmental and Life Sciences, ul. Grunwaldzka 53, 50-357 Wroclaw, Poland, e-mail: barbara.patorczyk-pytlik@up.wroc.pl

*Research financially supported by grant No 2 PO6R 10329. 
Zawartość Se w chwastach łąkowych $\left(70 \mu \mathrm{g}\right.$ Se $\cdot \mathrm{kg}^{-1} \mathrm{sm}$.) była ok. 2-krotnie większa niż określona dla traw (32 $\mu \mathrm{g}$ Se $\cdot \mathrm{kg}^{-1} \mathrm{sm}$.). W tej grupie roślin największą kumulację Se wykazywał Equisetum arvense L. (103 $\mu \mathrm{g} \mathrm{Se} \cdot \mathrm{kg}^{-1} \mathrm{sm}$.), najmniejsza Taraxacum officinale (59 $\mu \mathrm{g} \mathrm{Se} \cdot \mathrm{kg}^{-1} \mathrm{sm}$.). Zarówno w trawach, jak i chwastach zawartość selenu była istotnie zależna od ilości tego pierwiastka w glebach. Dla gatunków: Dactylis glomerata L., Arrhenatherum elatius L., Poa pratensis L. oraz Taraxacum officinale o ilości nagromadzonego Se decydowała również zasobność gleb w C-org. i S-og.

Słowa kluczowe: Se, gleby, trawy, zioła.

\section{INTRODUCTION}

With their rich botanical composition, meadows are of special importance among permanent grasslands. The chemical composition of green forage or hay harvested from natural meadows is superior to that of simplified, more uniform meadows with high contribution of grasses. Likewise, their botanical composition and suitability for animal nutrition are better. The fact that animals receive much meadow forage, especially in spring and sumer, raises an important question of its quality.

Selenium is one of the chemical elements which are essential for good growth and development of animals. When fodders, especially those used in cattle and sheep rearing, are deficient in, selenium, animals may suffer from inferior fertility, higher incidence of miscarriages or dietary muscular dystrophy, commonly known as the white muscles disease (DЕ̨вSKI 1992, ZABєосKI 1991).

The content of selenium in meadow sward is conditioned by a number of physical and chemical properties of soils, including their Se richness (ZABŁOCKI 1991, MikKelsen 1989, LASER 2004, White et al. 2004), as well as the composition of plant species which grow on a given soil (Whiтe et al. 2004, HuANG and Wu 1991). GuPTA and MacLeod (1994) as well as White et al. (2004) report that differences in Se accumulated by plants become more distinct on soils rich in this element, yet they remain hardly noticeable on Se poor soils. LASER (2004) stated that even when growing on soils deficient in selenium deficit, herbs and leguminous plants featured higher content of this element than grasses.

Based on extensive research in this field, WHITE et al. (2004) classified plants regarding their ability of Se accumulation. These authors made a list of plants growing on grassland, arranging them from according to the Se content, from the lowest to the highest one: Lolium multiflorum, Dactylis glomerata, Lolium perenne, Trifolium pratense, Phleum pratense, Rununculus repens, Holcus lanatus, Vicia villosa, Taraxacum officinale, Trifolium repens. HuANG and WU (1991) found that deeply rooted plants contain more selenium than those possessing a shallow root system. JoHNSON (2005) has empirically demonstrated that plant species characterized by a high demand for sulfur also contain higher quantities of selenium. 
The aim of this work has been to assess selenium content in soils and in selected grass species collected from 97 meadows situated in the region of Wrocław.

\section{MATERIAL AND METHODS}

The assessment of the differences between meadow plant species with respect to their ability of selenium uptake was done based on determination of Se in 10 species of meadow plants collected during the first cut from 97 meadows in the vicinity of Wrocław. Our investigation involved 5 grass species: orchard grass (Dactylis glomerata L.), tall cat grass (Arrhenatherum elatius L.), meadow bluegrass (Poa pratensis L.) and meadow foxtail (Alopecurus pratensis L.), meadow soft grass (Holcus lanatus L.) as well as 5 plant species of meadow herbs: common dandelion (Taraxacum officinale), common milfoil (Achillea millefolium L.), field horsetail (Equisetum arvense L.), ribwort plantain (Plantago lanceolata), and common dock (Rumex acetosa L.). The species selected for the examination did not occur on all grassland areas, therefore the analyzed samples were of different sample sizes. Grasses and herbs were collected from the whole area of grassland and an average sample was formed from 15-20 initial samples. Soil samples were collected from two depths: $0-5 \mathrm{~cm}$ and $5-20 \mathrm{~cm}$, and from the same sites the plant material originated from. Soil samples underwent determination of basic physicochemical properties: granulometric composition - according to Bouyoucos-Casagrande's aerometric method, modified by Prószyński, organic C content by Tiurin's method, soil sorption capacity (T) by Kappen's method, $\mathrm{pH}$ in $\mathrm{mol} \mathrm{KCl} \cdot \mathrm{dm}^{-3}$ using the potentiometric method, the content of total sulfur by Butters and Chenry's method. Selenium content was assayed using the AAS method combined with hydride generation in a Spectra 220 FS Varian device with a VGA-76 attachment: in soils after sample mineralization according to Beach's method (1992) and in plant material with the method described in the Annex to the Ordinance of the Minister for Agriculture and Development of Rural Areas dated 23 January 2003 (Journal of Laws No 66).

\section{RESULTS AND DISCUSSION}

The soils subjected to the examination were characterized by considerably varied properties (Table 1). Analysis of their granulometric composition showed that 41 samples featured sand granulation, $33 \%$ was represented by loamy soils and $25 \%$ belonged to silty soils. Nearly half of the meadows was situated on very light soils $(27 \%)$ or light soils $(21 \%)$ of strong acid or acid 
Table 1

Some properties of soils

\begin{tabular}{|c|c|c|c|c|c|c|c|c|}
\hline Layer & \multicolumn{4}{|c|}{$0-5 \mathrm{~cm}$} & \multicolumn{4}{|c|}{$5-20 \mathrm{~cm}$} \\
\hline Properties & $\min$ & $\max$ & mean & $\begin{array}{l}V \\
\%\end{array}$ & $\min$ & $\max$ & mean & $\begin{array}{l}V \\
\%\end{array}$ \\
\hline Fraction $<0.02 \mathrm{~mm}$ & & & & & 3.1 & 50 & 22 & 60 \\
\hline $\mathrm{pH}_{\mathrm{KCl}}$ & 3.7 & 7.3 & & 18 & 3.8 & 7.5 & & 18 \\
\hline Organic $\mathrm{C}, \mathrm{g} \cdot \mathrm{kg}^{-1}$ & 7.8 & 72.7 & 24.8 & 43 & 7.4 & 68.0 & 21.2 & 60 \\
\hline Total S, $\mathrm{mg} \cdot \mathrm{kg}^{-1}$ & 88 & 1189 & 392 & 58 & 26 & 1260 & 343 & 67 \\
\hline
\end{tabular}

$V$ - coefficient of variation

reaction. Medium - heavy soils provided for $28 \%$ of the whole scope of samples. The remaining samples belonged to heavy soils. The content of organic $\mathrm{C}$ in the analyzed samples (Table 1) did not differ from the one determined by KUCHARZEWSKI et al. (2004) regarding meadow soils in 16 districts of Lower Silesia.

Natural content of selenium in soils ranges from 0 , to $2 \mathrm{mg} \cdot \mathrm{kg}^{-1}$ (Borowska, Koper 2007). According to Piotrowska (1984), its value for Polish soils reaches $40 \mathrm{up}$ to $640 \mu \mathrm{g} \mathrm{Se} \cdot \mathrm{kg}^{-1} \mathrm{dm}$. Having more organic matter, meadow soils contain higher quantities of Se than arable soils (HARTFIELD, BAHNERS 1988, TRAFIKOWSKA, KUCZYŃSKA 2000). An average content of selenium assayed in the examined soil samples (Table 1) was similar to that reported by Piotrowska (1984), i.e. $277 \mu \mathrm{g} \mathrm{Se} \cdot \mathrm{kg}^{-1} \mathrm{dm}$., comparable to the mean value for soils in whole Poland. The latter value was nearly twice as high as the data reported by ZABŁOCKI (1991), who analyzed meadow soils in the former Province of Szczecin, but half the average value determined by Trafikowska and KuCzyŃska (2000) for meadow soils in the vicinity of Bydgoszcz.

When analyzing selenium content in the soil samples collected from meadows with particular plant species (Table 2), it is worth noticing that lower Se content was detected at the sites where meadow soft grass was growing, in the 0-5 cm layer, as well as in both soil levels overgrown with common dock. Except for meadow foxtail, meadow soft grass and ribwort plantain, the soil collected from the 0-5 cm level showed higher Se content than deeper layers of soil.

The content of Se in 5 grass species ranged from 7 to $199 \mu \mathrm{g} \mathrm{Se} \cdot \mathrm{kg}^{-1}$ $\mathrm{dm}$. The average value calculated for this group of plants $\left(32 \mu \mathrm{g} \mathrm{Se} \cdot \mathrm{kg}^{-1}\right.$ $\mathrm{dm}$.) did not differ from the value reported by LASER (2004). Among the 295 grass samples subjected to analysis, 33\% featured Se content lower than $20 \mu \mathrm{g} \mathrm{Se} \cdot \mathrm{kg}^{-1} \mathrm{dm}$, while only $15 \%$ contained more than $50 \mu \mathrm{g} \mathrm{Se} \cdot \mathrm{kg}^{-1} \mathrm{dm}$. The highest contribution of samples featuring a very low Se content $(<20 \mu \mathrm{g}$ 
Table 2

Se content in soils under the examined plant species $\left(\mu \mathrm{g} \mathrm{Se} \cdot \mathrm{kg}^{-1} \mathrm{dm}\right.$.)

\begin{tabular}{|c|c|c|c|c|c|}
\hline $\begin{array}{l}\text { Species } \\
\text { Layer }\end{array}$ & $\begin{array}{l}\text { Dactylis } \\
\text { glomerata }\end{array}$ & $\begin{array}{l}\text { Poa pratensis } \\
\text { L. }\end{array}$ & $\begin{array}{l}\text { Arrhenatherum } \\
\text { elatius L. }\end{array}$ & $\begin{array}{l}\text { Alopecurus } \\
\text { pratensis L. }\end{array}$ & $\begin{array}{c}\text { Holcus } \\
\text { lanatus L. }\end{array}$ \\
\hline \multicolumn{6}{|c|}{ Grasses } \\
\hline $0-5 \mathrm{~cm}$ & $\frac{290}{42-851}$ & $\frac{294}{70-851}$ & $\frac{284}{42-851}$ & $\frac{279}{80-851}$ & $\frac{265}{72-708}$ \\
\hline$V \%$ & 58 & 60 & 58 & 57 & 59 \\
\hline $5-20 \mathrm{~cm}$ & $\frac{265}{43-923}$ & $\frac{272}{43-923}$ & $\frac{266}{43-923}$ & $\frac{308}{92-923}$ & $\frac{274}{93-582}$ \\
\hline$V \%$ & 61 & 64 & 61 & 62 & 50 \\
\hline \multicolumn{6}{|c|}{ Herbs } \\
\hline $\begin{array}{l}\text { Species } \\
\text { Layer }\end{array}$ & $\begin{array}{l}\text { Taraxacum } \\
\text { officinale }\end{array}$ & $\begin{array}{c}\text { Achillea } \\
\text { millefolium L. }\end{array}$ & $\begin{array}{l}\text { Plantago } \\
\text { lanceolata }\end{array}$ & $\begin{array}{l}\text { Equisetum } \\
\text { arvense L. }\end{array}$ & $\begin{array}{c}\text { Rumex } \\
\text { acetosa } \mathrm{L} .\end{array}$ \\
\hline $0-5 \mathrm{~cm}$ & $\frac{278}{42-851}$ & $\frac{284}{42-851}$ & $\frac{277}{83-851}$ & $\frac{317}{70-851}$ & $\frac{236}{70-624}$ \\
\hline$V \%$ & 57 & 54 & 56 & 61 & 52 \\
\hline $5-20 \mathrm{~cm}$ & $\frac{253}{43-908}$ & $\frac{266}{43-908}$ & $\begin{array}{c}273 \\
102-908\end{array}$ & $\frac{294}{73-908}$ & $\frac{217}{73-477}$ \\
\hline$V \%$ & 57 & 62 & 58 & 64 & 45 \\
\hline
\end{tabular}

$V$ - coefficient of variation

$\mathrm{Se} \cdot \mathrm{kg}^{-1} \mathrm{dm}$ ) was detected among meadow soft grass $(43 \%)$ and orchard grass (41\%), and the lowest one was detected in meadow foxtail (22\%). Comparing the mean values calculated for the examined grass species (Table 3), it is possible to state that the highest amount of selenium was detected in samples of tall cat grass, while the lowest value characterized meadow soft grass. In the latter species, the low Se content could have resulted from the Se content in the soil being lower than that determined for the remaining soil samples collected from underneath the other grasses, in the $0-5 \mathrm{~cm}$ soil layer. According to the data reported by WHITE et al. (2000), meadow soft grass is a species accumulating in its tissues higher quantities of selenium than orchard grass or meadow bluegrass. The influence of the low Se content in soils on the amount of this element in this species samples can be confirmed by the average Se content in the meadow sward from which meadow soft grass was isolated being lower than Se values determined for the remaining grass species.

Considerably more selenium than in meadow grasses was found in meadow herbs (Table 3). Similar correlations were reported by HARFIELD and BAHNERS (1988), HuANG and Wu (1991), OPITZ von BobERFELd (2002) and LASER (2004). The content of selenium in this plant group showed high diversity and 
Table 3

Se content in examined grass species and in meadow sward they were collected $\left(\mu \mathrm{g} \mathrm{Se} \cdot \mathrm{kg}^{-1} \mathrm{dm}\right.$.)

\begin{tabular}{|c|c|c|c|c|c|}
\hline Species & $\begin{array}{l}\text { Dactylis } \\
\text { glomerata }\end{array}$ & $\begin{array}{c}\text { Poa pratensis } \\
\text { L. }\end{array}$ & $\begin{array}{c}\text { Arrhenatherum } \\
\text { elatius L. }\end{array}$ & $\begin{array}{l}\text { Alopecurus } \\
\text { pratensis L. }\end{array}$ & $\begin{array}{c}\text { Holcus } \\
\text { lanatus L. }\end{array}$ \\
\hline $\begin{array}{l}\text { Number } \\
\text { of samples }\end{array}$ & 73 & 62 & 68 & 55 & 37 \\
\hline Mean & 31 & 28 & 46 & 29 & 24 \\
\hline Range & $7-118$ & $7-66$ & 9-199 & $7-63$ & $8-105$ \\
\hline$V$ & 70 & 56 & 88 & 49 & 77 \\
\hline \multicolumn{6}{|c|}{ Mean for grasses $32 \mu \mathrm{g}$ Se·kg-1 dm., $V=85$} \\
\hline \multicolumn{6}{|c|}{ Meadow sward } \\
\hline Mean & 41 & 42 & 40 & 40 & 35 \\
\hline Range & $15-130$ & $15-130$ & $17-130$ & $17-102$ & $15-130$ \\
\hline$V$ & 56 & 56 & 56 & 57 & 68 \\
\hline Species & $\begin{array}{l}\text { Taraxacum } \\
\text { officinale }\end{array}$ & $\begin{array}{c}\text { Achillea } \\
\text { millefolium } \mathrm{L} .\end{array}$ & $\begin{array}{l}\text { Plantago } \\
\text { lanceolata }\end{array}$ & $\begin{array}{l}\text { Equisetum } \\
\text { arvense L. }\end{array}$ & $\begin{array}{c}\text { Rumex } \\
\text { acetosa } \mathrm{L} .\end{array}$ \\
\hline $\begin{array}{c}\text { Number } \\
\text { of samples }\end{array}$ & 52 & 57 & 36 & 26 & 31 \\
\hline Mean & 59 & 70 & 63 & 103 & 68 \\
\hline Range & $15-220$ & $16-765$ & $15-178$ & $16-650$ & $16-216$ \\
\hline$V$ & 67 & 137 & 62 & 131 & 74 \\
\hline \multicolumn{6}{|c|}{ Mean for herbs $70 \mu \mathrm{g} \mathrm{Se} \cdot \mathrm{kg}^{-1} \mathrm{dm} ., V=113$} \\
\hline \multicolumn{6}{|c|}{ Meadow sward } \\
\hline $\begin{array}{l}\text { Arythmetic } \\
\text { mean }\end{array}$ & 40 & 40 & 37 & 44 & 36 \\
\hline Range & $15-130$ & $17-130$ & 18-102 & $19-130$ & $15-130$ \\
\hline$V$ & 55 & 53 & 47 & 49 & 74 \\
\hline
\end{tabular}

$V$ - coefficient of variation

ranged from 15 to $765 \mu \mathrm{g} \mathrm{Se} \cdot \mathrm{kg}^{-1} \mathrm{dm}$, with the variation coefficient ranging from 62 (Plantago lanceolata ) to 137 (Achillea milefolium L). The calculated arithmetic mean of Se content in aerial parts of soft plants for 202 samples of this plant group equaled $70 \mu \mathrm{g} \mathrm{Se} \cdot \mathrm{kg}^{-1} \mathrm{dm}$. When comparing the selenium content in the five analyzed herb species, it is possible to conclue that the highest ability to accumulate this microelement was demonstrated for field horsetail (Equisetum arvense L). Markedly lower quantities of selenium were absorbed by common milfoil, common dock and common plantain, while the lowest accumulation rates belonged to common dandelion. However, even these species of meadow herbs accumulated twice as much selenium as grasses. 
The statistical analysis proved that both selenium content in both grasses and meadow herbs was significantly dependent on the amount of this element in the both analyzed soil layers (Table 4). In the case of such species as Dactylis glomerata, Poa pratensis L., Arrhenatherum elatuis L., and Taraxacum officinale, the amount of accumulated Se was also affected by organic $\mathrm{C}$ as well as total sulfur. These properties, however, did not considerably effect the Se accumulation by Holcus lanatus L., Achillea milefolium L., oraz Equisetum arvense L.

Table 4

Simple correlation coefficients between Se content in plants and some properties of soils

\begin{tabular}{|c|c|c|c|c|c|c|}
\hline \multirow{3}{*}{ Properties } & \multirow{3}{*}{$\begin{array}{c}\text { Layer } \\
\mathrm{cm}\end{array}$} & \multicolumn{5}{|c|}{ Se content in plants } \\
\hline & & \multicolumn{5}{|c|}{ grasses } \\
\hline & & $\begin{array}{l}\text { Dactylis } \\
\text { glomerata }\end{array}$ & $\begin{array}{c}\text { Poa } \\
\text { pratensis }\end{array}$ & $\begin{array}{l}\text { Arrhenathe- } \\
\text { rum elatius }\end{array}$ & $\begin{array}{c}\text { Alopecurus } \\
\text { pratensis }\end{array}$ & $\begin{array}{l}\text { Holcus } \\
\text { lanatus }\end{array}$ \\
\hline \multirow{2}{*}{ Organic C } & $0-5$ & 0.63 & 0.43 & 0.46 & 0.31 & n.s. \\
\hline & $5-20$ & 0.49 & 0.40 & 0.42 & 0.32 & n.s. \\
\hline \multirow{2}{*}{ Total S } & $0-5$ & 0.49 & 0.38 & 0.34 & 0.34 & n.s. \\
\hline & $5-20$ & 0.54 & 0.44 & 0.36 & 0.35 & n.s. \\
\hline \multirow{2}{*}{ Total Se } & $0-5$ & 0.73 & 0.79 & 0.54 & 0.40 & 0.64 \\
\hline & $5-20$ & 0.67 & 0.71 & 0.53 & 0.37 & 0.45 \\
\hline \multicolumn{7}{|c|}{ Herbs } \\
\hline & & $\begin{array}{l}\text { Taraxacum } \\
\text { officinale }\end{array}$ & $\begin{array}{c}\text { Achillea } \\
\text { millefolium }\end{array}$ & $\begin{array}{l}\text { Plantago } \\
\text { lanceolata }\end{array}$ & $\begin{array}{c}\text { Equisetum } \\
\text { arvense }\end{array}$ & $\begin{array}{l}\text { Rumex } \\
\text { acetosa }\end{array}$ \\
\hline \multirow{2}{*}{ Organic C } & $0-5$ & 0.43 & 0.32 & n.s. & n.s. & 0.37 \\
\hline & $5-20$ & 0.36 & n.s. & n.s. & n.s. & 0.40 \\
\hline \multirow{2}{*}{ Total S } & $0-5$ & 0.31 & n.s. & 0.36 & n.s. & n.s. \\
\hline & $5-20$ & 0.32 & n.s. & 0.29 & n.s. & n.s. \\
\hline \multirow{2}{*}{ Total Se } & $0-5$ & 0.82 & 0.57 & 0.39 & 0.42 & 0.86 \\
\hline & $5-20$ & 0.76 & 0.45 & 0.41 & 0.36 & 0.78 \\
\hline
\end{tabular}

significant at $p<0.05$

n.s. - not significant

\section{CONCLUSIONS}

1. The herbs subjected to examination contained significantly more selenium than grasses.

2. The examined meadow plant species showed different abilities to accumulate Se. 
3. With respect to grasses, markedly more Se was determined in tall cat grass (Arrhenatherum elatuis L.), while field horsetail (Equisetum arvense L.) contained a significantly higher amount of Se than the meadow herbs.

4. Accumulation of selenium by the analyzed meadow plants was considerably dependent on the amount of this microelement in both soil layers subjected to examination.

5. The effect of organic $\mathrm{C}$ and total $\mathrm{S}$ content in plants was conditioned by properties of particular plant species.

\section{REFERENCES}

BEACH L.M.1992. Determination of As, Sb and Se in different environmental samples by hydride generation. Varian Optical Spectroscopy Instruments. Wood Dale, Illinois, USA AA-105. Instruments AT work, 1-7.

Borowska K., Koper J. 2007. Rozmieszczenie selenu w glebach. W: Selen - pierwiastek ważny dla zdrowia, fascynujacy dla badacza [Distribution of selenium in soil. In: Selenium an element that matters to health and fascinates researchers). WierzBickA M., BulsKA E., Pyrzý́ska A., Wysocka I., Zachara B.A. (red.): 31-45. (in Polish)

Dॄ̨вSKI B. 1992. Wskaźnikowa rola mleka $w$ ocenie hiposelenozy u bydta [A diagnostic role of milk in the assessment of hyposelenosis). SGGW Warszawa, pr. habilit. 37 ss. (in Polish)

Gupta U.C., MacLeod J.A.1994. Effects of various source of selenium fertilization on selenium concentration of feed crops. Can. J. Soil. Sci., 74:285-290.

Hartfield W., Bahners N. 1988. Selenium deficiency in the Federal Republic of Germany. Biol. Trace Elem. Res., 15: 1-12.

Huang Z.Z., Wu L. 1991. Species richness and selenium accumulation of plant in soils with elevated concentration of selenium and salinity. Ecotoxicol. Environ. Sef., 22,3: 251-266.

Johnson L.2005. Essential trace elements and food quality. NFJ Seminar no 370 "Essential trace elements for plants, animals and humans". 15-17.08.2005. Reykjavik, Iceland, 15-17.

Kucharzewski A., Nowak L., DęBowski M.2004. Wptyw niektórych wtaściwości gleby na zawartość form rozpuszczalnych i całkowitych $\mathrm{Zn}, \mathrm{Cu}$ i $\mathrm{Mn}$ w glebach województwa dolnoślqskiego [Effect of some soil properties on the content of soluble and total $\mathrm{Zn}, \mathrm{Cu}$ and $\mathrm{Mn}$ in soils of Lower Silesia). Zesz. Probl. Post. Nauk Rol., 502:189-197. (in Polish)

LASER H. 2004. Pflanzenbauliche Ansätze zur Selen-Versorgung von Mutterkühen und Fleischrindern in Weidesystemen. Habilitationsschrift Universität Gieâen. 213.

Mikkelsen R.L., Haghnia G.H., PAGe A.L., Bingham F.T. 1989. Factors affecting selenium accumulation by agricultural crops. In: Selenium in agriculture and the environment. Ed. JACOBS L. Amer. Soc. Agron. Soil. Sci. Soc. Amer, 65-94.

OPITZ VON BOBERFELD 2002. Selenathaltlige mehrnährstoff - düngergaben und ihr effekt auf die selen- und schwefel- konzentration in Abhängigkeit von hauptbestandsbildner, aufwuchs and aufwand. Planzenbauwissen - schawten. 6,2:84-92.

Piotrowska M. 1984. Zwartość selenu w uprawnych glebach Polski [Content of selenium in cultivated soils in Poland). Rocz. Glebozn., 36(1): 147-149. (in Polish)

TRAFikowska U., Kuczý́sKa I. 2000. Zawartość selenu w glebie pól uprawnych i tąk okolic Bydgoszczy [Content of selenium in soils of arable fields and meadows near Bydgoszcz). Zesz. Probl. Post. Nauk Rol., 471: 567-572. (in Polish) 
ZABŁOCKI Z. 1991. Selen $w$ powierzchniowych poziomach gleb oraz lucernie obszarów niedoborowych [Seelenium in surface layers of soil and in aflalfa growing in deficit areas). Mat. VII Symp. „Mikroelementy w rolnictwie”, Wrocław, 109-113. (in Polish)

Whiте P.J. 2004. Interaction between selenium and sulfur nutrition in Arabidopsis haling. J. Experim. Bot., 55 (404): 1927-1937.

Rozporzqdzenie Ministra Rolnictwa $i$ Rozwoju Wsi $z$ dnia 23 stycznia 2003 r. w sprawie metodyki postępowania analitycznego $w$ zakresie określania zawartości sktadników pokarmowych $i$ dodatków paszowych $w$ materiatach paszowych, premiksach $i$ mieszankach paszowych. Dz.U. nr 66, poz. 614. [Annex to the Ordinance of the Minister for Agriculture and Development of Rural Areas of 23 January 2003 on the methods of analytical procedure regarding determination of nutrients and fodder additives in fodder materials, premixes and mixtures. Journal of Laws No 66, item 614) (in Polish) 
